\title{
Where has all the stuffing gone?
}

\section{British universities seem ill-equipped to fight back against their most obdurate critic, the government whose instrument of policy on higher education they are supposed to be.}

BRITISH universities have had a rotten time in the past few years. Is it possible that their painful experiences have made them incapable of resisting the continuing pressure from their critics, chiefly the British government? That is the charitable explanation of the mood of last week's conference, organized by the universities' trade association, the Committee of ViceChancellors and Principals, which was ostensibly intended as a forum for hammering out a reply to the government's green paper on higher education, published earlier this year (see Nature 315, 265; 1985). That the committee should have it in mind to reply to the government's tactless document by producing the one that should have been published, cheeky though it may be, is sound. The danger is that the result will not be a defence but a kind of apology, like that of the legendary servant girl who was in trouble for having produced a child of unknown parentage and whose defence was along the lines of "but it's only a small one".

To be fair, the universities seem to have taken account of one of the features of the British educational system that cries out for reform. Several speakers at last week's conference spoke of the need for a broader curriculum both at the secondary schools from which the universities recruit their students and even within universities themselves. It is high time, in the apparently endless brooding about the failure of the British system of higher education, that more serious attention was paid to the value of a liberal education. Indeed, the need that something should be done to make British education less narrow has been urgent at least since the rapid expansion of the early 1960s. For much of that time, British academics have been chief among those seeking to resist change. Only reluctantly, in the past few years, have they been won round to a reform of the pattern of school education that will allow a modest broadening of the education of intending students, no doubt in part because they appreciate that it cannot harm the university system if it becomes more common that students should follow four-year undergraduate courses (as they do already in Scotland). The trend is nevertheless a sign of grace.

\section{Research}

On research, the universities seem less sure of themselves. The tenor of the British government's complaint is that too much of what passes for research at British universities is academic in character, unlikely to contribute to national prosperity. This is the spirit in which the budget cuts have been put forward as beneficial incentives to be more practical. Driving academics looking for funds into the arms of industry is bound to make their work more directly relevant to national prosperity, the argument goes. The reply on behalf of the universities last week was curiously muted. Universities have a snobbish disdain for industry (as the green paper complains)? "That cannot be true now; just look at the difficulty we have in persuading graduates to stay on for research!" Universities have been slow to assist with the transfer of technology to industry (another complaint)? "Ah well, things are changing; some universities are making substantial sums of money out of industrial liaisons." The weakness in such replies is that they concede the principles of the complaints the government has been making. It would be permissible, and in the end rather safer, to insist that only individual universities can usefully shape their own destiny.

What more robust defence can there be? What British universities should recognize is that there is no reason why the system of higher education to which they collectively belong should be capable both of contributing to the development of technology and of preserving the old traditions of scholarship and research, but that the flaw in the British government's complaints over the past six years is that it is unreasonable to expect that each single institution will contribute in the same way. Constitutionally, the vice-chancellors' committee cannot easily abandon the polite convention that all universities are equal, which is especially crippling when it is acknowledged that the essence of an effective reply to the British government's complaints must be a plea that greater diversity is now, as for decades, the most urgent need. The truth is that British higher education has been made too uniform as a consequence of government policies and the polite conventions of the academic life. Only within such a framework will it be feasible for some universities and polytechnics to make their way in the world by concentrating on the needs of industry and for others to do what they already do well, scholarship and academic research. But will not greater diversity flow from the plan of the University Grants Committee to begin allocating a part of its subvention for universities on the basis of a judgement of the quality of the research which is at present carried out? The first steps in this direction will have been taken six months or so from now. The most obvious danger is that the result will be to strengthen the universities that are already strong, and publicly marking out the others as secondrate, undeserving of more than basic support and thus incapable of self-improvement.

\section{Budget}

The impending row about this discriminatory allocation of money is only one of the several novel crises now facing British universities. Another is the continuing decline of the budget, estimated to be shrinking still at between one and a half and two per cent a year when allowance is made for increased costs and the difficulty of settling salary increases within the government's national allowance. The University Grants Committee has said that it will not be long before it is forced to recommend that one or more institutions should be closed, but that it will not shoulder the invidious task of saying where the axe should fall. That crisis could come sooner rather than later, perhaps as early as next May. Then, to round out the sense of gathering gloom, the function of the grants committee itself is being reviewed. The excuse is a minor reference in a report on the efficiency of universities published earlier this year, but it seems unlikely that the committee appointed for the purpose will constrain itself within a framework of accountancy. The ideal is that the review should settle on principles for supporting all kinds of higher education, polytechnics as well as universities, and should then work out a way in which the grants committee can function more as a monitor of success or failure than as a source of funds. But who will say what is success? On last week's showing, the vicechancellors are not up to the job. Nor, by the evidence of this year's green paper, is the British government. Might that not be the lasting function of a grants committee with a broader membership? 